\title{
Indonesian postgraduate students' intercultural communication experiences in the United Kingdom
}

\author{
Sarah Aisha ${ }^{1}$ dan Deddy Mulyana ${ }^{2}$ \\ ${ }^{1,2}$ Universitas Padjadjaran, Bandung, Indonesia
}

\begin{abstract}
Despite the increasing number of Indonesian postgraduate students studying overseas, including in the United Kingdom, not many studies have been done on their intercultural communication experiences and academic engagement. This research aims to investigate Indonesian postgraduate students' intercultural communication experiences and academic engagement in the United Kingdom. In this study, we address the following research question: What are the hindering factors and the facilitating factors of Indonesian postgraduate students' academic engagement within their courses of study? A qualitative research method is used in this study, based on semi-structured interviews with 13 participants. The results of the study indicate that the students are more engaged in some areas, such applying deep learning strategies by connecting ideas, and less engaged in others, such as interacting with academic staff. Several interrelated factors were indicated as contributing to facilitating or hindering academic engagement which include sociocultural, institutional, and individual factors. The hindering factors consists of the transition to a new academic environment, intense academic workload, 'expert' or 'boring tutors, linguistic barriers, and having feelings of uneasiness. Conversely, the facilitating factors consist of institutional support service, course design, caring and casual tutors, learning from prior experiences, having the initiative to ask, and realizing to make the most of the opportunity.
\end{abstract}

Keywords: academic engagement; higher education; intercultural communication experiences; international students; postgraduate students

\section{Pengalaman komunikasi antarbudaya mahasiswa pascasarjana di United Kingdom}

\begin{abstract}
ABSTRAK
Walaupun jumlah mahasiswa pascasarjana Indonesia di luar negeri, termasuk di Inggris, meningkat, sampai saat ini tidak banyak penelitian yang telah dilakukan tentang pengalaman komunikasi antarbudaya dan keterlibatan akademik mereka. Studi ini bertujuan untuk meneliti pengalaman komunikasi antarbudaya dan keterlibatan akademik mahasiswa pascasarjana Indonesia di Inggris. Peneliti ingin menjawab pertanyaan berikut: Faktor-faktor apa yang menjadi kendala dan yang memudahkan keterlibatan akademik mahasiswa pascasarjana Indonesia dalam studi mereka. Untuk menjawab pertanyaan tersebut, dilakukan penelitian kualitatif dengan wawancara semi-terstruktur dengan 13 informan. Hasil penelitian menunjukkan bahwa para informan lebih terlibat di beberapa area, seperti mengaplikasikan strategi belajar mendalam dengan menghubungkan ide-ide, dan tidak begitu terlibat di area yang lain, seperti berinteraksi dengan staf akademik. Beberapa faktor yang berkaitan terbukti memudahkan atau menjadi kendala bagi keterlibatan akademik mereka, mencakup faktor sosiokultural, institusional, dan individual. Faktor kendala terdiri dari transisi ke lingkungan akademik yang baru, beban akademik yang berat, dosen 'ahli' dan 'membosankan', kendala bahasa, dan perasaan khawatir. Sebaliknya, faktor yang memudahkan terdiri dari dukungan institusional, desain kuliah, dosen yang penuh perhatian, pengalaman belajar sebelumnya, inisiatif untuk bertanya, dan kesadaran untuk memanfaatkan peluang.
\end{abstract}

Kata-kata kunci: keterlibatan akademik; pendidikan tinggi; pengalaman komunikasi antarbudaya; mahasiswa internasional; mahasiswa pascasarjana

Korespondensi: Sarah Aisha, S.Psi., MA., Prodi Ilmu Komunikasi Fikom Unpad, Jl. Raya Bandung Sumedang KM 21, Jatinangor 45363, Indonesia.Email: sarahaisha@yahoo.com 


\section{INTRODUCTION}

This research aims to explore Indonesian postgraduate students' academic engagement in the United Kingdom (UK). In general, academic engagement is defined as student activities both inside and outside of the class, including class attendance, the process of learning, efforts to accomplish assignments and meet deadlines, and the passion to interact with lecturers/tutors and interest in the lesson. It is related to their motivation, cognition, and behaviour (Alrashidi et al., 2016).

Despite the fact that literature contains large numbers of research covering international students, very little research focused specifically on Indonesian students, especially their academic engagement. Previous studies that have examined Indonesian students were conducted in the context of education in US (Mukminin, 2012; Mukminin \& McMahon, 2013; Mukminin, Yanto, \& Yanto, 2013), Australia (Bahri, 2013; Novera, 2004), Taiwan (Chen, Liu, Tsai, \& Chen, 2015), and Korea (Mulyana \& Eko, 2017). None of these studies have investigated the Indonesian students in the context of education in UK.

Indonesian students entering another country, especially with the purpose of study, have to adjust themselves not only to the social and cultural norms in general, but also to the new and unfamiliar academic environment. Several studies have reported that Indonesian students overseas faced difficulties and academic challenges during their studies. Mukminin (2012) found that Indonesian doctoral students in US experienced a phase of academic shock at the beginning of their studies. In another work, it was also reported that issues related to academic engagement were also faced, including the amount of academic work required, unfamiliarity with classroom dynamics and faculty - student relationships, issues with peers and academic tutors, and language barriers (Mukminin \& McMahon, 2013). Meanwhile, Novera (2004) particularly noted certain issues associated with classroom interaction and student-teacher relationships in a study of Indonesian postgraduate students in Australia. She linked these issues to cultural differences in teaching and learning practice. The difficulties and academic challenges faced by Indonesian students in other countries might also be faced by those studying in UK.

In the context of UK higher education, international students' intercultural communication experiences were suggested as playing a significant role in their learning (Turner \& Robson, 2008). Moreover, the experiences which includes their learning characteristics could be viewed as being incorporated in their personal background, perception of learning situation, as well as their learning approach (Prosser \& Trigwell, 1999). Thus, this suggests that the Indonesian postgraduate students learning experience have generally come from how they perceive their intercultural experience as well as their own learning habits in their own cultural group.

As international students carry their own cultural background, they have to adapt crossculturally to the new academic environment. Therefore, some degree of learning challenges will be faced. However, these challenges arose not only due to cultural difference, but also due to the unfamiliarity with the academic requirements of UK higher education institutions (Brooks \& Walters, 2011). These problems are related to lack of academic skills, unfamiliarity with different teaching and learning approaches, and tension in student - academic staff relationships. Although the sample were mostly Chinese, this may suggest that Indonesian students studying in UK might also face similar challenges. However, it is also possible that the challenges and engagement are unique, as influenced by their cultural experiences. Therefore, to further understand the academic engagement of this particular cultural group, it is helpful to look at the existing research.

Issues related to linguistic barriers were experienced within the areas of writing, reading, speaking, and listening. Although Bahri (2013) did not explore the issue further, both Novera (2004) and Mukminin and McMahon (2013) noted that writing was one of the most problematic areas cited. This includes choosing appropriate words and deciding the flow (Mukminin \& McMahon, 2013). Limited by the questionnaire to gather data, Novera (2004) assumed that it was because of the grammatical and syntactical structure differences between Indonesian and English. However, conducting a more in-depth study using semi-structured interviews, Mukminin and McMahon (2013) attributed it to the lack of skills. Meanwhile, 
reading difficulties arose as the materials were perceived as requiring them to have advanced English comprehension level (Novera, 2004). Additionally, lack of speaking and listening skills were also mentioned as hindering factors in class discussions and presentations. For the former, it was related to unfamiliarity with the topic, nervousness, low self-confidence (Novera, 2004), lack of practice as well as personality factors (Mukminin \& McMahon, 2013). Whereas the latter was related to the pace of speech which results in difficulty understanding the topics being discussed (Mukminin \& McMahon, 2013). Interestingly, Mukminin and McMahon (2013) stated that except for writing, other linguistic skills were reported to progress gradually overtime which built self-confidence and courage to take part in class discussions. However, it was unclear on what period of study the data was taken, which makes it difficult to indicate how long it took for the skill to develop.

In a study investigating doctoral students in Australia, Mukminin and McMahon (2013) reported that the unanticipated overwhelming amount of coursework due within a limited completion time caused shock and stress, besides the high level of difficulty. It has hindered some of the students' full engagement, more specifically during class discussions as they failed to understand the reading materials within a limited timeframe. Similarly, the issue of academic workload was also noted in Novera's (2004) study, although the participants' degree of postgraduate study was unspecified. It was reported that time management issues were faced as they were not used to completing assignments while also having to read a lot. Although both studies reported similar issues, at this point it is useful to consider that the academic workload might differ between different levels of study, as well as different disciplines.

In terms of student - academic staff relationships, unfamiliarity with the nature of relationship seems to be highlighted as an issue. Novera (2004) reported that students' felt awkward having to address academic staff using first names. In addition, Indonesian students were noted to show reluctance in asking for suggestions, advice, or help regarding challenges and obstacles (Mukminin \& McMahon, 2013), and also giving critical comments (Novera,
2004). In western education context, the latter might be considered as classroom passivity whereas in Indonesian context it is a culturally appropriate behavior (Novera, 2004). Using the concept of power distance (Hofstede, 2005), this was attributed to 'power distance' difference in Indonesian educational system, which is more formal and hierarchical. However, Mukminin and McMahon (2013) succeeded to capture the possibility of more frequent engagement with academic staff overtime, as the students reported to feel more comfortable with the informal nature of relationship after one semester.

Despite lacking consensus in terms of conceptualization, various views of student engagement are useful in providing hints to understand the construct. In general, students' engagement is an outcome of various interrelated influences, which might include an individual, institutional, and also sociocultural factors.

A limited body of research concerning international students' experience indicates that these students face problems that might hinder their academic engagement, including linguistic barriers. Although similar issues were also faced by Indonesian students in a western educational context, some problems might differ from other cultural groups due to different cultural experiences. Therefore, their academic engagement experiences might also be different.

\section{METHOD}

Thisresearchis basedonaphenomenological theoretical perspective which emphasizes human subjectivity and consciousness as its core of study. To do so it used a qualitative method with semi-structured interviews. The overall purpose of the study is to explore the academic engagement of Indonesian international students within the context of the UK higher education institution. The study attempts to establish patterns both shared across contexts and unique to a particular context (Greene, 2005). In other words, it also recognizes the centrality of culture. Thus, it can provide better insights to understand the academic engagement of Indonesian postgraduate students in the context of their courses of study in UK higher education institutions.

As Klingner and Boardman (2011) suggested, the data obtained through a qualitative inquiry could add 'depth and breadth' 
to understand the influence of contextual factors not available through the quantitative inquiry. It offers potential to better understand in what context and under what circumstances the students are engaged or disengaged in. Semistructured interviews with 13 participants were conducted to collect the qualitative data. Besides offering flexibility and adaptability in the process of exploring an issue (Robson \& McCartan, 2016), interviews allowed the researchers to understand the students' perspective (Flick, 2014).

The research participants were Indonesian postgraduate students under the Indonesian Endowment Fund for Education scholarship undertaking Master studies in UK. They consist of five males and eight females. Most of participants ranged in age between twenties and early thirties. Six participants were obtained in 2016 from a database provided in the scholarship recipients' social network group. The other seven participants were obtained and interviewed in 2017.

The interview schedule contained openended questions related to the participants' academic experience within their course of study. The interviews were held in Bahasa Indonesia since the participants felt more comfortable expressing themselves orally in Bahasa Indonesia, although in several occasions English was used to express themselves. Interview excerpts were translated to English.

Most of the 13 interviews were conducted at the location of the participant's choice, either at university or their place of residence. The interview sessions took place from June 2016 to September 2017.

Although timing was considered in all interviews, the length varied as some interviews were longer than others. In most cases, the interviews were approximately twenty to forty minutes except for one that lasted for over seventy minutes.

The content of the data gathered varied across 13 interviews due to different academic engagement experiences across universities and disciplines. In order to find the general pattern of the data, thematic analysis was considered as an appropriate method to use. As a practical method, it offers flexibility in analyzing qualitative data through themes that emerged during the interview (Braun \& Clarke, 2006). More specifically, it involves exploring the data based on relationships, commonalities, and differences across data sets (Gibson \& Brown, 2009).

All the participants were undertaking Master's Degree. Five participants were studying in two London-based Universities, while eight were studying in other universities outside London: Birmingham, Bristol, Glasgow, Lancaster, Leeds, and Manchester. The participants were majoring in diverse fields of education such as Engineering, Business, Education, Anthropology, Journalism, and Psychology. Seven participants started their course in September 2015, while six in September 2016.

\section{RESULTS AND DISCUSSION}

After conducting thematic analysis of the interview data, three main themes emerged as factors that have hindered the academic engagement of the students: sociocultural, institutional, and individual factors. The theme 'institutional' was further sub-divided into: Intense Academic Workload and "Expert" or 'Boring Tutors", while the theme 'individual' was categorized into: Linguistic Barriers and Uneasiness.

While describing their engagement experiences, most of the participants talked about their transition to their new academic environment as challenging, especially at the beginning of the first term. They used words such as 'tough', 'hectic', 'dizzy', 'struggling', 'it needs courage and self-confidence', 'lack of guidance', 'tired', 'lonely', 'homesick', 'lost', and 'tense' to describe their transitional phase experience.

Having to adjust with a different academic culture was mentioned by most of the participants. More specifically, regarding the difference related to learning method, including the pace and the academic culture of reading and writing. A participant, for instance, pointed out that he needed to get used to the assignments and assessments given:

The first term was challenging, [...] it was the time for adaptation with the life and learning method here. And there are also differences with, especially the assignments here and the assessment in Indonesia. In Indonesia, usually there are exams, but here it's $100 \%$ or $90 \%$ essays. 


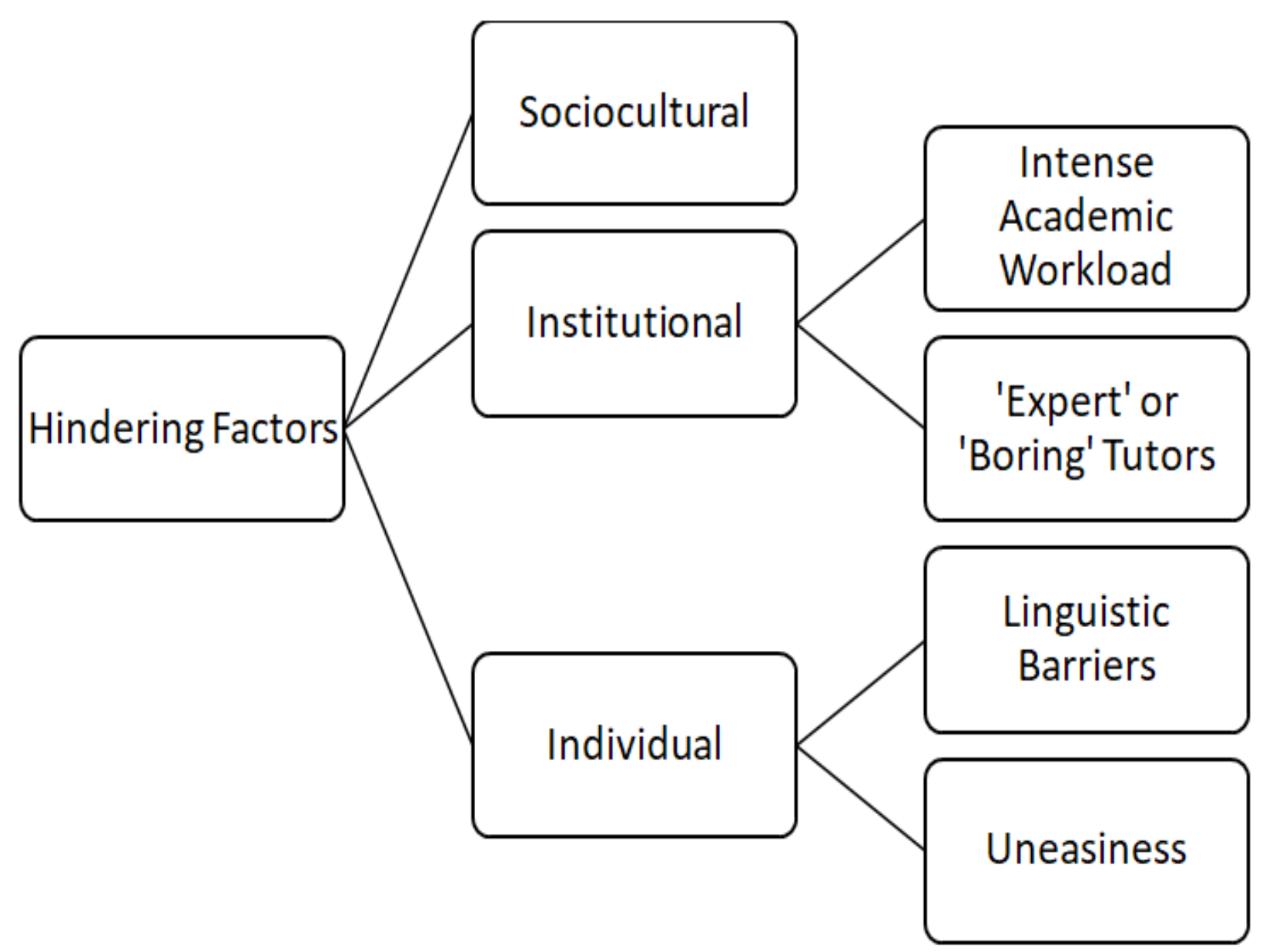

Source: Authors' research findings, 2018

Figure 1 Academic engagement hindering factors

Hence, having to adjust themselves academically was not the only concern. In terms of social adjustment, some participants said that their challenge was related to not having social relationships, as they were the only Indonesian among other peers from other cultures, predominantly Chinese. For example, a participant described his experience:

I was tense, I had a headache. First, because I had no friends here. And when I enrolled in my course, there were no Indonesians there. Then, here I hadn't got any close friends.

Intense academic workload. As each participant was enrolled in different course of study, the type of assignments also varied. Some had individual assignments whereas others had group assignments. Nevertheless, over a half of the participants talked about the challenge of having several assignments simultaneously given at the same time, which could include two or three assignments with deadlines close to each other. They talked about how it hindered them to work to their full potential as they had to 'juggle' between other activities, such as working on other assignments, attending classes, or learning other subjects. To illustrate, a participant expressed her experience in tackling her assignments:

There were many (essays), and at the same time, there was group work... So, it wasn't the best actually. While working on it, ah, just finish it. [...] What's important was for it to be done, so (I) could work on another one.

The 'Expert' and 'Boring' Tutors. Tutors, especially their way of delivering the lesson was mentioned by some participants as affecting their comprehension or interest towards the lesson. They said that they did not like a certain module because the tutor's instructional practice was considered unsuitable for their level of understanding. In other words, the tutors taught them as if they already had good grasp of the 
subject. For example, a participant talked about why she did not like a certain module:

The tutor was 'super senior'. So, he was too genius. He assumed that other people understood, everyone understood. Thus, in class it was next slide, next, you know this right? Next, ah, I don't need to explain this. So, he taught based on his intuition.

In addition, an uninteresting style of lesson delivery, such as 'boring' or using a 'flat tone' also affected the participants' interest. A participant explained that it made half the students in class fall asleep during the lesson.

Linguistic Barriers. Unlike teaching and learning in Indonesian universities, the medium of instruction used in UK is English. Almost all the participants talked about linguistic barriers which have affected them during their study. The areas of linguistic skills mentioned include writing, speaking, listening, and reading.

Amongst the four skill areas, writing was the most frequent activity that the participants struggle with. The majority of participants stated that they faced problems when they had to write for exams or assignments. One participant stated, "The journals were difficult to comprehend. This caused difficulties to write different academic essays". In particular, the difficulty mentioned was related to diction or essay structure.

In terms of speaking, some participants talked about their difficulty to express their thoughts in academic settings such as class discussions. One participant stated, "We were required to give our opinions in our classes. It took us so much energy".

Besides writing and speaking, listening to lectures was also considered as challenging for some participants. One participant said, "The tutors spoke too fast that made me perplexed". In particular, certain accents have hindered them from comprehending lectures, as expressed by a participant:

It's African English... It's so hard, right?

The pronunciation, word per word. What was he talking about? Sometimes I couldn't get it.

More specifically, a participant who studied in Glasgow mentioned the thick, different, and strange accent of Scotch English that it took her much time to understand the language.

While these participants faced difficulty listening to certain non-standard English speakers, some other participants found listening to native speakers as more difficult. However, it was for a similar reason, pronunciation.

Additionally, reading journal articles was pointed out by a few participants as difficult for two reasons. Firstly, because they were not accustomed to reading as well as discussing reading; and secondly, because of specific terms contained in the articles. Thus, regarding reading skills, a few other participants emphasized that future Indonesian postgraduate students should prepare themselves for reading English materials and develop reading strategies such as skimming and scanning so that they become used to it.

Feeling Uneasy. For a few participants, the feeling of uneasiness arose in large classes with people that they don't know well. They mentioned that it hindered them to convey their thoughts or take part in class discussions. One participant said, "I was not confident to speak, especially when the class was large". Another talked about his is fear of being judged by his classmates that he hasn't known well while another mentioned about feeling intimidated, as she put it:

In large classes it is really difficult. It's like the room was really big, there are many people, and [...] hard to carry yourself. I think it's a psychological factor. It's so intimidating.

In addition, in terms of not taking part in class discussions, another participant mentioned that it was because he was still processing the information given by the tutor, as he said, 'My mind was still thinking about the previous point, I was like... dragged.'

In terms of factors that have facilitated the academic engagement of the students, only two themes emerged during the interview data analysis, consisting individual and institutional factors. These themes were also divided into sub-themes as presented in Figure 2.

Institutional Support. The presence of either academic or non-academic institutional support were mentioned by some participants as helping them through their studies. The 


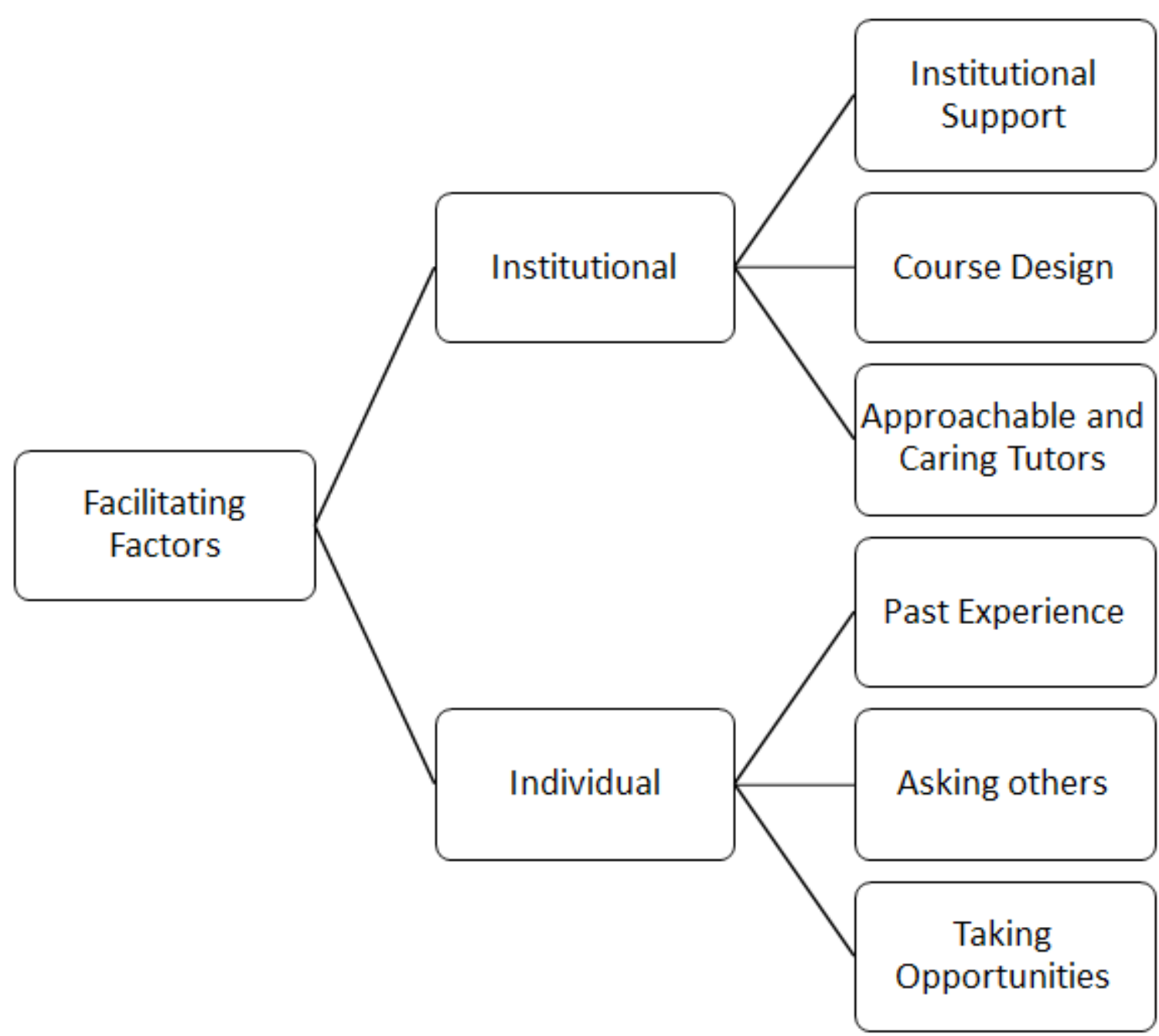

Source: Authors' research findings, 2018

\section{Figure 2 Academic engagement facilitating factors}

academic support includes academic writing workshops, one-on-one tutorials, and easy access to computers and academic journals in libraries, to help the participants write essays. In addition, non-academic support provided by academic staff or counsellors has also helped several participants go through their studies, by talking and sharing about their performance, expectations, as well as challenges faced. To give an example, a participant described the support provided by his program director as well as the course director:

They gave suggestions so that your adaptation could be smoother... Then, the personal tutorial which was not about our study, in the beginning and middle of the course, it helped a lot. They gave us time slots... we just need to fill in our names, so we had a chance to come to them.

Additionally, one participant appreciated the fast internet, the many electric outlets, the vending machines, and the close distance cafeteria provided by the university. Another mentioned many e-mails sent to her every week informing her non-academic programs, such as mindfulness classes, provided to support the students well-being.

Course design. Having group tasks has given several participants opportunities to collaborate and discuss course materials with their peers as they have group meetings outside class. In addition, having a system in which students were given responsibility to become a panelist was seen by a participant as a 'forcing' him to prepare himself more and take part in class, as he said: 'What helped was this, the schedule for becoming panelists was very good, because it was like were forced to contribute.'

Approachable and caring tutors. Some participants mentioned that having a close relationship with a tutor made them feel 
more comfortable, as they could express themselves more freely without hesitation. A few participants emphasized that the tutor's personal approach is a significant factor for them while learning. For example, a participant talked about how his tutor influenced him to put in more effort:

The tutor contributes a lot in whether I learn the subject or not. If the tutor is interesting, easy to understand, and if he remembers your name, I'll give a lot of effort. I will really like the lesson. I mean, the personal attention he gives [...] So, it's actually a simple thing, but other tutors don't do it.

The characteristics of the tutors reported were those who not only talk about academic matters, but also about personal and life matters, such as family, future goals or other things such as holidays or how they were doing.

Having previous experience. In general, for the majority of the participants, their second term was perceived as better compared to the first term. They explained that they 'have learnt from the first term'. Some participants mentioned that they have learnt learning strategies that work better for them in order to enhance understanding of the subject or meet the course requirements, as one of them put it, 'I understand better of what I should understand,' while another said, 'I could plan things better since I have experience from the first term, it helped a lot.'

Additionally, another participant pointed out that she could manage her readings better since she already had better comprehension by reading many materials during the previous term. While most participants emphasized that previous learning experience during the first term has helped them to adjust better academically, one participant stressed that it helped her socially, to interact with peers in her class by knowing what topics to talk about.

Asking others. At some point of their study, most of the participants have experienced facing problems while feeling unsure of how to tackle them. These include personal or academic issues, such as how to do a certain assignment, or inadequate understanding of course materials. Some participants said that asking other people have helped them to face their difficulties.
Academic staff and peers were the most frequently mentioned as sources they go to when addressing their academic concerns. In terms of the former source, a few participants mentioned that they asked them concerning reading recommendations for their essays. A participant asked for reassurance on whether his assignments matched the tutor's expectations. Another participant said that she talked with a student adviser when she had difficulties in doing assignments. In addition, asking peers in order to get insights or to have better comprehension was also mentioned by the participants. More specifically, the ones that they identify as 'smart', as described below:

... when I faced difficulties I asked the boss, the highest level of the "food chain", the smartest in class. I started to ask him, but not too much.

In fact, asking help from other sources was also mentioned. A participant said that asking former colleagues in the related field has given her insights for her assignments. Meanwhile, in relation to personal concerns that might affect her study process, asking help from a counsellor also supported her. In brief she pointed out, 'identify your problems, and find a person that might be able to help you.'

Eventually, asking around has also been the most cited suggestion for prospective Indonesian postgraduate students. Some participants stressed that it is important for these students to know what they will face, including 'the environment, the people, and the education'. Seeking information from various sources could help gaining background knowledge to help them 'survive' in the new environment. However, one participant emphasized the importance of considering the type of question asked, as she said:

We cannot ask general questions or come emptyheaded. You're going to be slaughtered, because the academic culture is, you ask something that you don't know because you have done research before you asked.

Making the most of the opportunity. Not all Indonesians have the chance to get a scholarship and become a postgraduate student in the UK. Some participants said that they have put in more effort or took chances to participate in 
class activities and discussions because they realized the opportunity and wanted to make the most it, as a student put it, 'I know I am here to learn.' A participant talked about taking the 'rare' chance to speak in front of classmates from other countries, while another described his effort to keep coming to a class although it was not compulsory. In addition, a participant expressed that although she struggled, she put in effort as she wanted to make the most of the opportunity to access knowledge:

This is the chance for me to learn all of that, which I might not have access to in Indonesia. [...] even though I was dogtired, [...] because this chance might not come again.

Additionally, a participant reported wanting to enrich her experiences by taking the opportunity to engage in extra-curricular activities, such as competitions and projects.

Findings from this study indicate that the students worked hard to master difficult content and meet tutor's expectations. Indeed, the condition of their scholarship requires them to put in effort to achieve academic grades needed. Taking a psychological approach to describe the state of engagement (Fredricks et al., 2004), it was indicated that the students were most frequently cognitively engaged as they invest effort in learning and apply deep learning strategies. However, it might also suggest that they were behaviorally engaged while working hard.

On the other hand, it was also shown that the students engaged less frequently on activities related to interactions with academic staff. This issue was also highlighted in previous studies involving Indonesian students overseas (Mukminin \& McMahon, 2013; Novera, 2004). However, it was indicated that other reasons lie beyond the unfamiliarity of the nature of student - academic staff relationship. Indeed, previous studies have pointed out the important role of intercultural experiences in learning (Turner \& Robson, 2008; Prosser \& Trigwell, 1999). While there is possibility that having previous experience studying in Indonesia-a higher 'power distance' sociocultural context - might affect the students' academic engagement, other factors might also play a role. Based on the limited interview data available, students' interactions with academic staff that have occurred was indicated to be influenced by a more engaging environment, such as the opportunities of having individual tutorials. However, at the same time, it also seems to be influenced by factors within the students, such as motivation, manifested in having the initiative to engage themselves through those tutorials. Thus, this implies that engagement is also influenced by both institutional and individual factors, as proposed by Kahu (2013).

Indonesian students overseas have to adjust themselves to a new social as well as academic environment with a different culture. Previous studies have documented 'academic shock' experienced by Indonesian students as part of their intercultural communication experiences in a western academic context (Mukminin, 2012; Novera, 2004). In this research, some participants reported feeling 'lost' and 'confused' at the beginning of the term, suggesting they have also faced 'academic shock'. Thus, this sociocultural factor might become a barrier to fully function as a postgraduate student within their course of study as they had to adjust themselves with the demanding academic requirements. Additionally, this finding is also consistent with earlier studies regarding challenges due to cultural differences faced by international students in the UK (Brooks \& Walters, 2011; Ryan, 2005).

Previous studies taking the behavioural perspective have also stressed institutional influences towards engagement (e.g. Kuh, 2009). In his proposed framework, Kahu (2013) divided it more specifically into psychosocial and structural influences. The first psychosocial influence identified as a hindering factor in this study was related to academic workload. It was found that participants could not engage fully in their tasks or class activities when dealing with amount of academic workload simultaneously given within a limited timeframe. This was similar to the experience of Indonesian postgraduate students in Australia (Novera, 2004) and US (Mukminin \& McMahon, 2013). Meanwhile, in certain circumstances, the tutors' instructional practice as another psychosocial influence also seem to contribute as a hindering factor.

In addition, individual factors were also found as hindering engagement. Although the participants have passed the IELTS test as a 
language requirement to enrol in their courses of study, linguistic barriers were reported as an issue. Previous studies have pointed out similar barriers faced by international students in UK (Liu, 2013). In line with Mukminin and McMahon (2013) and Novera's (2004) study, writing also tended to be the most problematic area for these participants, mainly because they were not used to the activity as it was not an academic culture in Indonesia. Furthermore, speaking and listening barriers were also reported to hinder engagement in class discussions and activities. However, it was unexpected that the variety of English accent and pronunciation were reported as the reason behind the issue. Thus, good English listening skills itself might not be sufficient, as the university community is increasingly becoming more diverse contributed by the globalisation of higher education (Walker, 2015). This suggests that intercultural communicative competence also needs to be developed in order to support successful communication with people from other cultures.

Overall, it was indicated that the participants were able to adjust themselves better in the second term. They reported that they have already learned from their experience during the first term and understood how the academic system works which enabled them to organise their learning better. This suggests that they have already integrated with the new sociocultural context which facilitated them to engage more in their course of study. This might also be supported by institutional and individual factors found in this study.

In relation to institutional factors, institutional support services as a psychosocial influence seem to play a significant role in helping engagement, as participants perceived benefitting fromit, for instance in terms of writing essays. This indicates that the participants' writing skills have improved overtime, which is in contrast to findings in Mukminin and McMahon's (2013) study. Previous studies (Okorocha, 2007; Smith, 2007; Kim, 2011) have indicated that another psychosocial influence, relationship between academic staff - student is the most important factor in learning within the university community.

In line with that of Kim (2011), it was also found that tutors adopting a personal approach might also facilitate engagement, as participants expressed enjoying the lesson more and willing to invest more effort. This might imply that affective engagement was bred, as they felt more comfortable interacting with the tutor, which rose their motivation to work harder. Thus, it seems to support the idea that engagement breeds engagement (Kahu, 2013). In addition, study discipline as a structural influence also seems to facilitate engagement. Similar to previous studies (Lam et al., 2014; Nelson Laird et al., 2008), teaching and learning also differ across the participants' courses of study. It was indicated that some participants had more opportunities to engage in learning with their peers while others do not. In addition, some that were given roles and responsibilities in class activities were also 'forced' to learn more about ideas and take part in class activities. This might imply that the student's academic engagement was also facilitated through courses that promotes collaboration and deep learning approach.

The main individual factor found to facilitate engagement was having the initiative to ask around from various sources and realising to make the most of the opportunity. The former could be seen as a form of behavioural engagement, as students interacted with the university community to ask for information, advice or suggestions. As a result, asking around has facilitated them to engage in another area, for instance in relation to their assignments. Numerous research have investigated the influence of motivation and self-determination towards students' academic engagement (Maulana et al., 2016; Reeve, 2012). It seems the participants' initiative to ask around has been driven by their motivation. In addition, realising that the participants have to make the most of the opportunity also seems to indicate the role of their self-determination to maximise their learning experience.

The findings of this study should be considered in the view of several limitations. First, the findings are not fully generalizable, as the 13 participants may not be representative of all of the Indonesian postgraduate students studying in UK. In addition, the study's findings might differ if more postgraduate students were included to develop more themes and categories. The study would even be more comprehensive if included undergraduate students as well, since there is a possibility that their academic 
engagement would be different from that of the postgraduate students.

\section{CONCLUSION}

In the academic engagement and intercultural communication experiences of Indonesian postgraduate students, they were found to be more engaged in some areas and less engaged in others. This study has shed a light in delineating intercultural educational/instructional communication between Indonesian postgraduate students and their social circles, especially their tutors. It enriches literature of Indonesian international students by providing a snapshot of Indonesian postgraduate students' academic engagement in UK.

Several interrelated factors were indicated to contribute in either hindering or facilitating their academic engagement, which include sociocultural, institutional, or individual factors in the case of hindering factors and institutional and individual factors in the case of facilitating factors. The theme 'institutional' was further sub-divided into: Intense Academic Workload and 'Expert" or 'Boring Tutors", while the theme 'individual' was categorized into: Linguistic Barriers and Uneasiness. However, further studies are needed to provide a more complete picture of the engagement experiences and understand its dynamic and situational nature in various circumstances. The process of learning in class, the tactics to study and meet deadlines, and patterns of interaction with lecturers and friends are interesting research topics to explore.

Indeed, the academic journey in this new sociocultural environment was found to be a challenge for these students. Thus, various strategies need to be done to enhance engagement by maximising facilitating factors while minimising hindering factors. Nevertheless, the responsibility relies on all parties: the students, the institutions and the scholarship provider. If all parties play their role, hopefully it will lead to optimised learning empowering these students to become impactful change makers for the betterment of the beloved home country, Indonesia.

Based on the findings of the study, the following suggestions are proposed to increase the Indonesian postgraduate students' learning within their course of study in UK. First, prospective students should prepare themselves more before enrolling in their course of study. Having an overall idea about the course they are going to enrol in might help students to engage more fully. In particular, understanding the academic culture, requirements, and the possible challenges that might be faced would be helpful. Thus, it is important to proactively seek and ask for information from various sources including the university, department, and also the Indonesian alumni. In addition, the prospective students also have to improve their academic skills, especially in the areas of writing and speaking, to engage more in their tasks as well as in class activities.

Second, in order to help these international students to succeed academically, universities and departments should also provide them with sufficient information on the UK academic and social culture. One way might be through ongoing mentoring or tutorials both before and during their study. The focus might also be on assisting international students in understanding the academic expectations, including possible challenges in relation to academic workload and strategies to tackle them. In addition, academic staff should also consider their approach in teaching international students, for instance by adjusting their pace of speech.

Third, the scholarship provider should help prospective students to prepare. This could be done by providing more helpful materials during pre-departure training and by focusing more on developing academic skills, intercultural competence, and intercultural communicative competence. In addition, conducting sharing sessions by alumni might also be useful to understand the learning expectations.

\section{ACKNOWLEDGEMENTS:}

The original data of this article derives from the qualitative part of Sarah Aisha's Master thesis (based on interviews with six informants) submitted to the Institute of Education University College of London - the United Kingdom in 2016 under the supervision of Dr. Erica McAteer. Thanks to Erica. Some more data has been added to the article based on Deddy Mulyana's interviews with seven informants conducted in London, UK, in 2017. The publication of this article has been permitted by UCL, UK. 


\section{REFERENCES}

Alrashidi, O., Phan, H.P. \& Ngu, B.H. (2016). Academic Engagement: An Overview of Its Definitions, Dimensions, and Major Conceptualisastions. International Education Studies 19 (12), 41-52.

Bahri, S. (2013). The Difficulties and Problems Faced by Indonesian Students While Studying in an Australian University. Visipena, 4(1).

Braun, V., \& Clarke, V. (2006). Using thematic analysis in psychology. Qualitative Research in Psychology, 3(2), 77-101.

Brooks, R., \& Waters, J. (2011). Student Mobilities, Migration and the Internationalization of Higher Education. Palgrave Macmillan.

Chen, Y.-L., Liu, M.-C., Tsai, T.-W., \& Chen, Y.-H. (2015). Religious Practices in Cross-Cultural Contexts: Indonesian Male Science Students' Adjustment in Taiwan. Journal of Counseling Psychology, 62(3), 464-475.

Flick, U. D. (2014). An Introduction to Qualitative Research. London: SAGE Publications Ltd.

Fredricks, J. A., Blumenfeld, P. C., \& Paris, A. H. (2004). School Engagement: Potential of the Concept, State of the Evidence. Review of Educational Research, 74(1), 59-109.

Gibson, W. J., \& Brown, A. (2009). Working with qualitative data. Los Angeles ; London: SAGE.

Greene, J. (2005). The generative potential of mixed methods inquiry 1 . International Journal of Research \& Method in Education, 28(2), 207-211.

Hofstede, G. H. (2005). Cultures and organizations : software of the mind $<$ span class="frbrsuppress" $>\quad / \& n b s p ;$ Geert Hofstede and Gert Jan Hofstede (Rev. and expanded 2nd ed. ed.). New York; London: New York; London : McGraw-Hill.

Kahu, E. R.(2013). Framing student engagement in higher education. Studies in Higher Education, 38(5), 758-773.

Kim, J. (2011). Student views on technology and teaching. Retrieved August 8, 2016, from https://www.insidehighered.com/ blogs/technology_and_learning/student views_on_technology_and_teaching.
Klingner, J. K., \& Boardman, A. G. (2011). Addressing the "Research Gap" in Special Education Through Mixed Methods. Learning Disability Quarterly, 34(3), 208218.

Kuh, G. D. (2009). What Student Affairs Professionals Need to Know about Student Engagement. Journal of College Student Development, 50(6), 683-706.

Lam, S.-f., Jimerson, S., Wong, B. P. H., Kikas, E., Shin, H., Veiga, F. H. (2014). Understanding and Measuring Student Engagement in School: The Results of an International Study from 12 Countries. School Psychology Quarterly, 29(2), 213232.

Liu, L. (2013). A qualitative study of international students experiences of engaging in learning on UK full-time taught masters programmes.

Maulana, R., Helms-Lorenz, M., \& van de Grift, W. (2016). The role of Autonomous Motivation for Academic Engagement of Indonesian Secondary School Students: A Multilevel Modelling Approach, The Psychology of Asian Learners. Singapore: Springer.

Mukminin,A.(2012). AcculturativeExperiences Among Indonesian Graduate Students in US Higher Education: Academic Shock, Adjustment, Crisis, and Resolution. Excellence in Higher Education, 3(1), 1436.

Mukminin, A., \& McMahon, B. J. (2013). International Graduate Students' CrossCultural Academic Engagement: Stories of Indonesian Doctoral Students on an American Campus. Qualitative Report, 18.

Mukminin, A., Yanto, F., \& Yanto, H. (2013). Beyond the Classroom: Religious Stressors and Adjustment among Indonesian Muslim Graduate Students in an American Graduate School. Online Submission.

Mulyana, D. \& Eko, B.S (2017). Indonesian Students' Cross-Cultural Adaptation in Busan, Korea. Jurnal Aspikom 3(2), 144156.

Nelson Laird, T. F., Shoup, R., Kuh, G. D., \& Schwarz, M. J. (2008). The Effects of Discipline on Deep Approaches to Student Learning and College Outcomes. Research in Higher Education, 49(6), 469-494. 
Novera, I. A. (2004). Indonesian Postgraduate Students Studying in Australia: An Examination of Their Academic, Social and Cultural Experiences. International Education Journal, 5(4), 475-487.

Okorocha, E. (2007). Supervising International Research Students (2nd ed.). London: Society for Research into Higher Education.

Prosser, M., \& Trigwell, K. (1999). Understanding Learning and Teaching: The Experience in Higher Education. Buckingham: Open University Press.

Reeve, J.M.(2012).ASelf-determination Theory Perspective on Student Engagement. In S. L. Christenson, A. L. Reschly \& C. Wylie (Eds.), Handbook of Research on Student Engagement. New York: Springer.

Robson, C., \& McCartan, K. (2016). Real World Research (4th ed.). United Kingdom: John
Wiley \& Sons Ltd.

Ryan, J. (2005). The Student Experience. Teaching International Students: Improving learning for all, 147.

Smith, R. (2007). An overview of research on student support: helping students to achieve or achieving institutional targets? Nurture or de-nature? Teaching in Higher Education, 12(5-6), 683-695.

Turner, Y., \& Robson, S. (2008). Internationalizing the University. London: Continuum.

Walker, P. (2015). The globalisation of higher education and the sojourner academic: Insights into challenges experienced by newly appointed international academic staff in a UK university. Journal of Research in International Education, 14(1), 61-74. 